\title{
Museumization of olive oil mills: instruments for conservation of the heritage of the olive grove culture
}

\author{
Diego Ortega Alonso, Juan Antonio Parrilla González
}

\begin{abstract}
Opposed to the historical concept of the olive oil mills as places just for transporting the fruit, milling and olive oil production, the growing interest in its museumization is turning them into gastronomic, cultural and ethnographic points of reference. This study analysed the components of the museumization of Andalusian olive oil mills, using the Qualitative Comparative Analysis (QCA) technique and employing the fuzzy-set approach (fsQCA). To that end, it draws on the definition of museum put forward by the more progressive elements of the International Council of Museums (ICOM). The main implication from the results is that olive oil mill professionals should adapt the museum offer according to the needs and aspects identified by the causality results of the model, and design museumization strategies with actions tailored to olive oil tourism, in order to more effectively tackle the transformations needed in the sector and enable the conservation of olive cultural heritage.
\end{abstract}

Keywords: olive oil mill, corporative museum, heritage, rural environment, olive grove culture, conservation, museumization, QCA

\section{Musealización de almazaras: instrumentos para la conservación patrimonial de la cultura del olivar}

Resumen: Frente al histórico concepto que arrastran las almazaras como lugares donde exclusivamente se produce el transporte del fruto, molturación y elaboración del aceite de oliva, el creciente interés por su musealización las está convirtiendo en referentes patrimoniales de carácter tanto gastronómico, como natural, cultural y etnográfico. Este estudio analiza los componentes de musealización de almazaras de Andalucía, mediante la técnica Qualitative Comparative Analysis (QCA) y empleando el planteamiento fuzzy sets (fsQCA), en virtud de los postulados de la definición de museo de las corrientes más progresistas del International Council of Museums (ICOM). La principal implicación de los resultados obtenidos es permitir a los profesionales de almazaras configurar las adaptaciones y la oferta museística en función de las necesidades y aspectos valorados, y diseñar estrategias de musealización con acciones adaptadas al turismo oleícola, para abordar las necesarias transformaciones del sector de manera más eficaz y para la conservación del patrimonio cultural olivarero.

Palabras clave: almazaras, museo corporativo, patrimonio, desarrollo rural, cultura del olivar, conservación, musealización, QCA

\section{Musealização dos lagares de azeite: instrumentos de conservação do património cultural do olival}

Resumo: Contrariamente ao conceito histórico dos lagares de azeite como locais de transporte de frutos, moagem e da produção azeite, o crescente interesse pela sua musealização está a transformá-los em pontos de referência gastronómicos, culturais e etnográficos. Este estudo analisou os componentes da musealização dos lagares de azeite andaluzes, utilizando a técnica de Análise Comparativa Qualitativa (CA) e empregando a abordagem fuzzy-set (fsQCA). Para isso, baseia-se na definição de museu apresentada pelas correntes mais progressistas do Conselho Internacional de Museus (ICOM). A principal implicação dos resultados obtidos é permitir aos profissionais de lagares configurar as adaptações e a oferta museuística em função das necessidades e aspetos avaliados, e conceber estratégias de musealização com ações adaptadas ao turismo oleícola, para fazer face às transformações necessárias do sector de forma mais eficaz e para a conservação do património cultural olivícola.

Palavras-chave: lagar de azeite, museu corporativo, património, meio rural, cultura do olival, conservação, musealização, QCA 


\section{Introduction}

Traditional olive groves, with their ancient olive trees and low tree density, are usually found in lands that are difficult to access. It prevents them from being mechanized and thus from competing in the markets with intensively and super-intensively farmed olive groves (Vilar Hernández et al. 2010). According to the 2019 report by Deoleo on the future of olive oil in Spain titled "Salvemos el Buen Aceite" (Let's Save the Good Oil) (2019), this could mean the potential disappearance of $20 \%$ of Spanish olive groves, which carries with it a negative environmental impact, since the maintenance of these crops slows desertification while their high $\mathrm{CO}_{2}$ absorption capacity contributes to the fight against climate change (Gómez-Limón \& Barreiro-Hurlé 2012). Their disappearance would mean the loss of this unique wealth, along with the cultural heritage inherent in the so-called "olive grove culture" (Cuesta \& Moya 2019). The abandonment of these olive grove landscapes, which are a candidate to receive World Heritage status from the United Nations Educational, Scientific and Cultural Organization (UNESCO) in the 2023 nomination cycle, would exacerbate the already worrying depopulation of rural areas and threaten an iconic landscape of the Mediterranean basin, a key element in the conservation of its ecosystem.

Heritage, understood as cultural capital that fosters the emergence of new services and with them new income (Scazzosi 2004; Farina \& Naveh 1993), attracts investment and encourages the appearance of related activities such as museums, alongside stable tourist services and secondary activities in rural environments (UNESCO 1962). UNESCO introduced the Outstanding Universal Value (OUV) statement (Gullino \& Larcher 2013) to assess the sites that form part of the world's cultural heritage, while having a positive economic, social and environmental impact, and an approach based on consensus and the effective deployment of heritage resources (Naveh \& Liebermann 1994).

There is a widespread global trend towards the museumization of spaces such as olive oil mills; this is reflected in proposals based on structures that explore cultural aspects (cultural and gastronomic heritage, ecosystems or historical events) and leverage experiential marketing focused on building knowledge and stimulating the senses Passebois Ducros \& Euzèby 2019). The strategy implemented by the olive oil sector in terms of carrying out actions that attract new target audiences to olive oil tourism involves new tourism practices based on experience, caring for the body, seeking out emotions, breaking out of the routine and stimulating the senses (Parrilla-González \& Pulido-Fernández 2017). These experiences have been scattered around different Mediterranean locations, but the main hub of such activity has been Andalusia, the primary olive oil producer in the region. These processes are being linked to cultural tourism, taking into account the perspectives and interests of local communities, which can also help governance bodies to strike a balance between the development of tourism and the conservation and safeguarding of heritage (UNESCO 2018).

This article begins with a review of the literature that provides a sound theoretical framework by defining the museum and the contributions of the different museum typologies related to the subject of this research. In the next section, the methodology is presented, which involves applying the Qualitative Comparative Analysis (QCA) technique using the fuzzy-set approach (fsQCA) to establish study variables on the degree of museumization of olive oil mills in Andalusia, and to generate proposals or models to enable the olive oil mills to incorporate museumization processes. The results are interpreted in the form of a discussion, linked to our research objective. Finally, a series of conclusions are drawn regarding the necessary implementation of these museum spaces and the results obtained in this study.

The objective of this research is to study the degree of museumization of olive oil mills in rural areas of Andalusia, according to the definition of a museum proposed by the most progressive sectors of the International Council of Museums (ICOM). Thus, the novelty of this research lies in the fact that no previous study in the literature has addressed the degree of museumization of oil mills. This article thus offers an innovative vision of the conservation of the olive grove landscapes and their rich heritage.

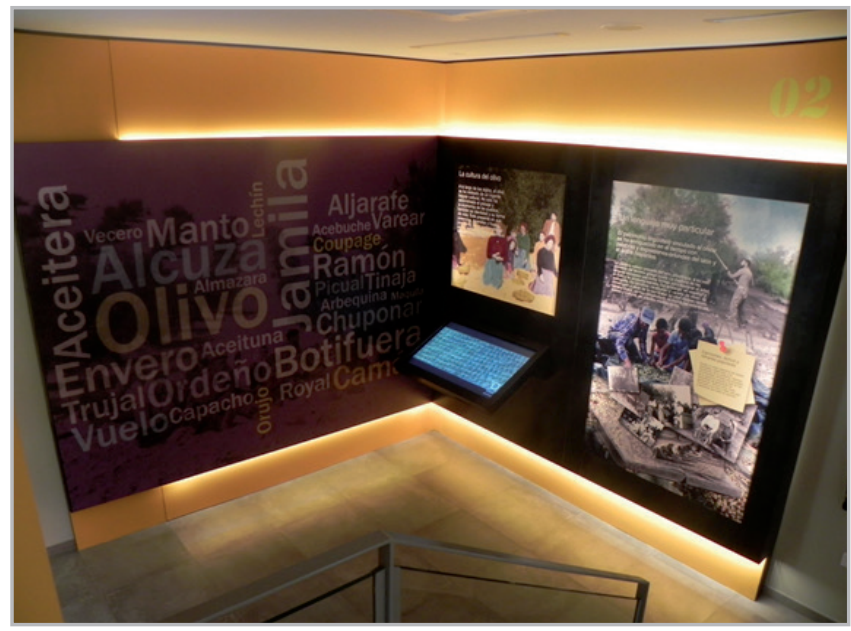

Figure 1.- Museumizated area from El Pilar olive oil mill cooperative, Villacarrillo, (Jaén, Spain). Source: own production.

\section{Theory}

Historically, what is known as olive grove culture has been linked to Mediterranean civilizations for five millennia and has played a fundamental role in this territory, defining its inhabitants'economic, social and cultural identities, bonding them together, and shaping the rural landscape (Loumou \& Giourgia 2003). These olive agroecosystems have played a crucial role in the ecology, economy, history and richness of the landscape and heritage of the Mediterranean (OjedaRivera et al. 2018), contributing to the sustainability of natural resources. The culture of olive oil represents a key development element for preserving the olive ecosystem, 
achieving the sustainable development of rural olive oil producing areas, and ensuring the future of the society that lives there (Mozas-Moral et al. 2020). In recent decades, traditional farming of olive trees has been threatened by socio-economic conditions, particularly the appearance of intensive and super-intensive olive groves that exacerbate the abandonment of traditional olive groves and cause the deterioration of ecosystems (Duarte et al. 2008). Olive oil mills, as entities sustained by the social economy, find themselves faced with a unique opportunity to develop local initiatives capable of harnessing the extraordinarily rich heritage of olive culture. Particularly notable among these initiatives is museumization.

\section{-The concept of museum in the context of olive oil mills}

The definition of a museum is an issue that has been under study for several decades and has been approached from a multidisciplinary perspective by professionals from various fields. Recently, this definition was the subject of debate within the ICOM, the international organization of museums and museum professionals that is supported by UNESCO and has consultative status with the United Nations Economic and Social Council.

The current definition of a museum was agreed on in 2007. According to said definition, museums are non-profit institutions of a permanent nature, which are open to the public and are at the service of society and its development, and which acquire, conserve, research, communicate and exhibit the tangible and intangible heritage of humanity and its environment for the purposes of education, study, and enjoyment.

At the last ICOM General Conference in Kyoto in 2019, the more innovative elements of ICOM were committed to implementing a new definition of a museum. The proposed new definition conceives the museum as a democratized, inclusive and polyphonic space for critical dialogue about the past and the future, which recognizes and addresses the conflicts and challenges of the present, while holding artefacts and specimens in trust for society, safeguarding diverse memories for future generations, and guaranteeing equal rights and access to heritage for all people (ICOM 2019). This trend advocates for the incorporation of concepts such as inclusion, to raise the visibility of the diversity of society and to be able to meet the needs of all audiences, as well as highlighting concepts such as transparency, dignity, justice, equality and well-being, underpinning the crucial role that museum professionals play in their respective societies (Ortega-Alonso \& PadillaFernández 2019). In light of these arguments, we formulate the following propositions:

- Proposition 1. Inclusive and democratized museum activities positively influence the degree of museumization of olive oil mills.

- Proposition 2. The use in the museum of artefacts and objects that have been preserved by society positively influences the degree of museumization of olive oil mills.



Figure 2.- Different elements of the museamization of olive oil mills: Figure 2A. Overhead view of the Museum of the Olive Oil Culture, Baeza (Jaén, Spain). Figure 2B. Interpretative area of historic olive oil mill in the same museum. Figure 2C. Interpretative museumization of stone olive oil mill with a donkey. Figure 2D. Interpretative taste of olive oil flavours by the visitors of museum. Source: own production.. 
The important role of olive oil mills as drivers of social development and structural change in municipalities (Mozas-Moral 2019), implies that the spaces occupied by agricultural cooperatives can be understood as a collective good. The community's sense of belonging to these spaces and the dialogue with them, endows them with significance and the capacity to stimulate dialectic and dialogic exchanges between all the parties involved, and of course means they are apt for museumization (El Museo Transformador 2020), using the communicative resources of museographic language for educational purposes. Based on these arguments, the following proposition is put forward:

- Proposition 3. Museumized activities that foster dialogue with the public positively influence the degree of museumization of olive oil mills.

Industrial heritage has a set of intrinsic characteristics that lie within cultural heritage. The reappraisal of this industrial heritage in the olive oil industry is part of the strategy being applied by olive oil mills in their museumization processes. In the specific case of historical industrial heritage, it has centred on production processes and disused machinery (Rojas-Sola et al. 2021). The perception of museum cultural heritage in Southern Europe, where these kind of mills are to be found, includes dimensions such as the capacity of preserving cultural assets and effectively communicating their importance, the quality of commodification for visitor use, and the ability to foster intercultural competence and promote intercultural dialogue (Carbone et al. 2020).

\section{— Museums, olive oil mills and olive oil tourism}

Tourism as an economic activity has had a great social and territorial impact since the 20th century (Blanco Romero et al. 2021). In general terms, olive oil tourism can be defined as an experiential tourist activity combining food, culture, and the production and knowledge of olive oil. (Parrilla-González et al. 2020). Such experiences are based on tourism, especially cultural tourism (Herrero 2011) and what is known as Special Interest Tourism (SIT). In the case of olive oil tourism, these may include activities such as visiting an olive grove; taking part in olive harvesting; visiting olive oil mills, interpretation centres or museums (Parrilla-González et al. 2020). There is another type related to industrial heritage tourism, which expands the cultural experience available to tourists. It is a way for them to find out about past and present economic activity, technology and working conditions, providing an inventory of heritage elements for conservation and research (Vargas-Sánchez 2015). In this context, the museumization of olive oil mills lies within the frame of the so-called corporate museums (Danilov 1991), as the companies that set them up need to appropriately share and transfer organizational memory to strengthen their brand identity (Matricano 2017).

The corporate museums are physically located in the mills themselves and are managed by the organizations (in this case, companies in the olive oil sector). They are powerful marketing tools (Bonti 2014) capable of transferring the set of knowledge and values held by the companies to the museum's customers and visitors. This transfer of knowledge and values has been called organizational memory (Danilov 1992; Katriel 1994; Nissley \& Casey 2002). However, when doing so it is essential to bear in mind the strategic lines of the definition of the museum in order to preserve the olive oil heritage and the organizational memory of these olive oil mills. The virtualization of these spaces have evolved to become museums designed for educational activities (Rojas-Sola et al. 2021). Thus, industrial agri-food facilities such as olive oil mills can become tourist resources and effective tools for the promotion and preservation of rural heritage and quality agri-food products (Armesto-López \& Gómez-Martín 2005; Kivela \& Crotts 2006). These arguments lead to the formulation of the following proposition

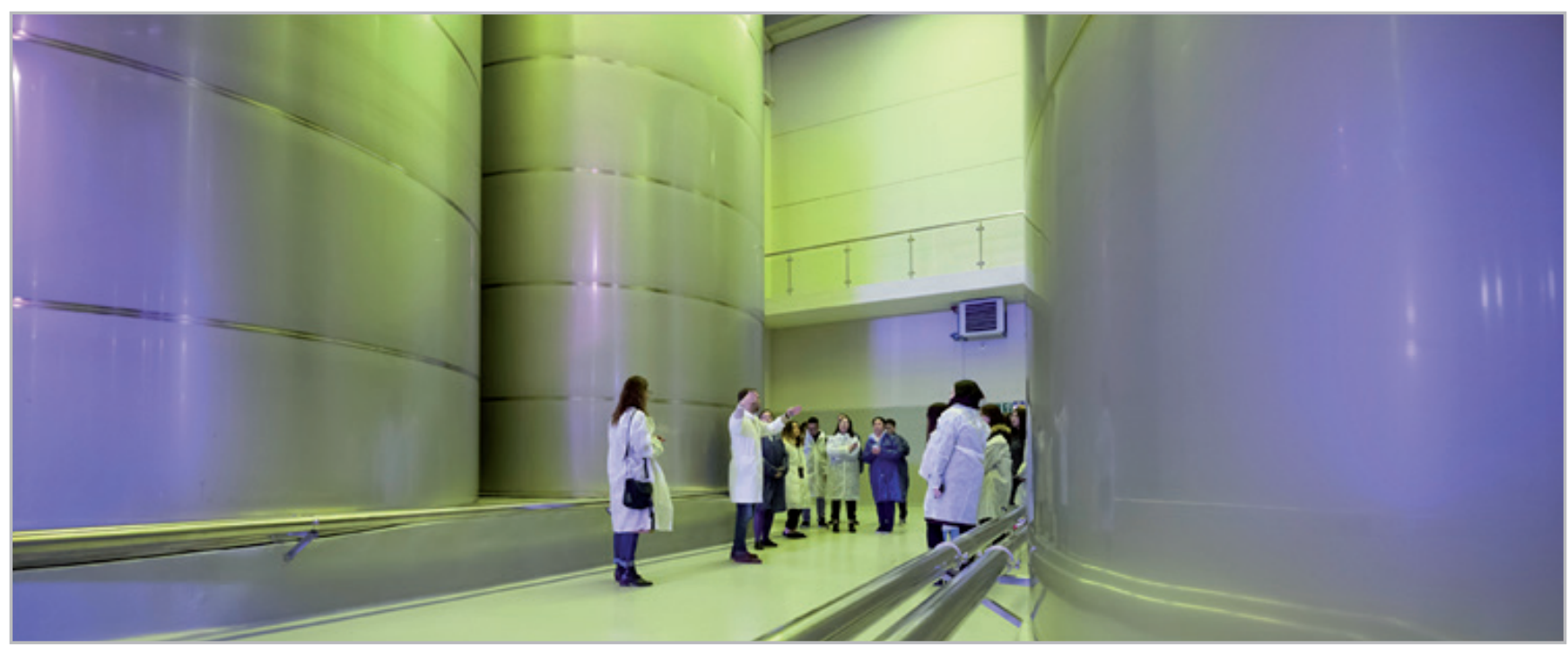

Figure 3.- Interpretative explanation for tourists of the olive oil cellar. Picualia olive oil mill, Bailén (Jaén, Spain). Source: own production. 
- Proposition 4. The activities linked to the rural and ethnographic development of the territory positively influence the degree of museumization of olive oil mills.

\section{— New ways of preserving rural heritage}

For decades, olive oil cooperatives have been undergoing a transformation through which they are becoming diverse ecosystems, spaces of social cohesion for the inhabitants of the rural environment where they are located, fomented by the different technological and social innovation strategies that have been implemented in recent years (SánchezMartínez et al. 2020). Olive oil mills are beginning to take on a role in which they become reservoirs of rural and ethnographic knowledge about the territory, which not only concerns the inhabitants of the municipalities where they are located, but also constitutes an element attracting the attention of those who see the rural environment as secondary (Ortega-Alonso \& Padilla-Fernández 2019). The presence of traditional crops and local products, the perpetuation of historical land uses and agricultural practices, and the existence of architecture related to agricultural activity are considered by UNESCO as the most important markers of integrity (Gullino \& Larcher 2013).

Some studies in the context of wine museums that address the wine tourism experience suggest that wine tourism professionals should integrate technology in an effective and non-intrusive way to provide visitors with an engaging, multisensory experience (Kirova 2020). CastilloCanalejo et al. (2020) segment food tourism according to the motivations for the visit, distinguishing between gastronomic experience and novelty; hedonism and leisure; and the visitor's relationship with the proposed experience. These activities are also based on interaction and dialogue between the public and museum spaces, shaping the demand for green or sustainable tourism (Montella 2017). Monitoring the relationship between the ecological footprint and tourism is a key issue in defining the overall sustainability of the tourism business (Gössling et al. 2002), in line with the positive outcomes that ecotourism has on environmental resources and local communities (Gössling 1999; Weaver 2002; Buckley 2009).

In order to define the type of museumized activities that take place in olive oil mills, a series of approaches have been developed that emerge from the definitions of the museum discussed above. Inclusive and democratized activities are part of the strategic vision of the new museology, which addresses innovative ways of presenting exhibitions and interacting with the public to accommodate a broad crosssection of society (O'Reilly \& Lawrenson 2020). Fostering dialogue with audiences through interaction therefore becomes crucial, as demonstrated by the decisive influence of museums as sites of experience and by studies on the
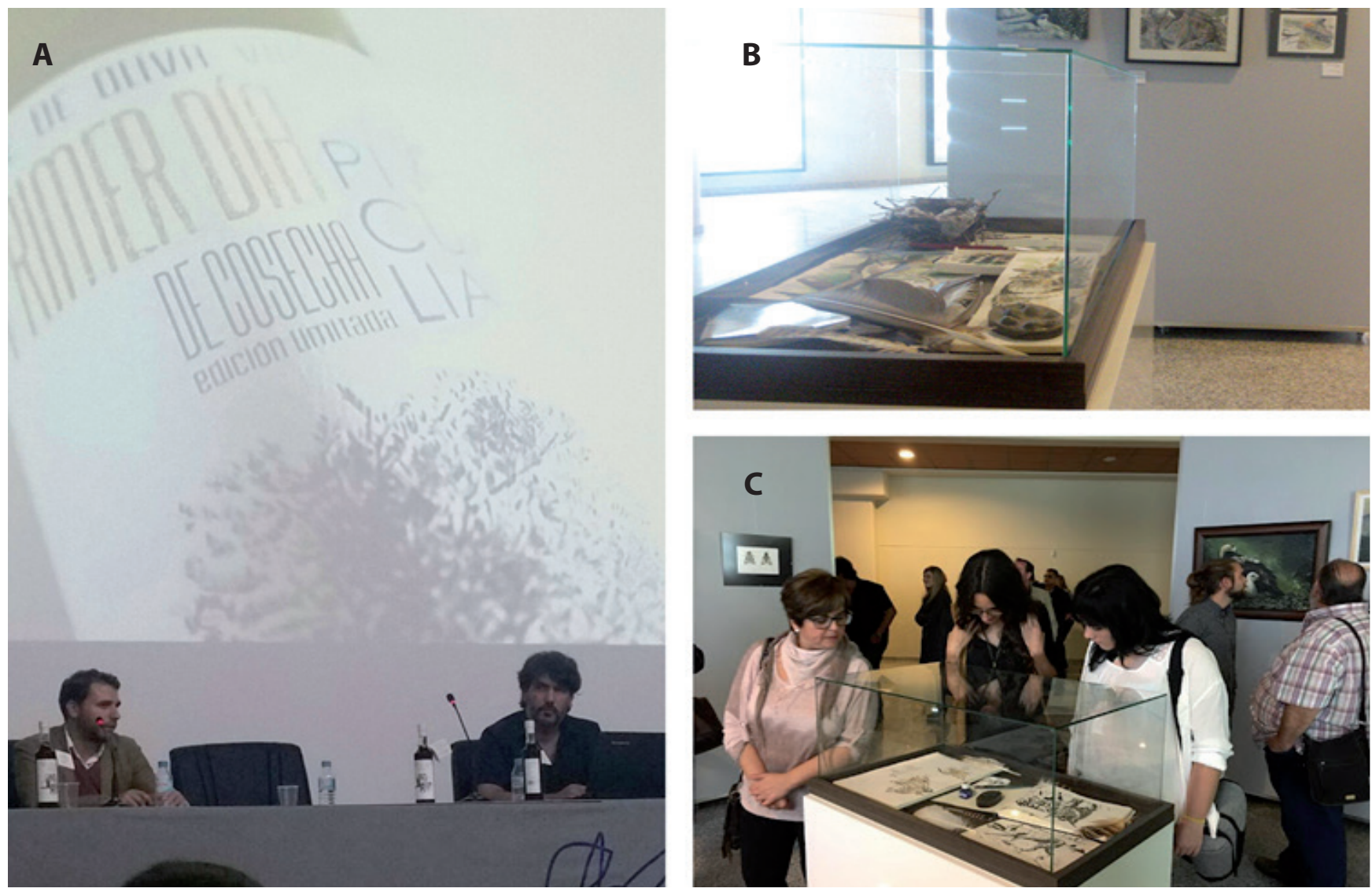

Figure 4.- A. The authors presenting First Day of Harvest in a museamizated olive oil mill. Figure 4B. Elements of a painting exhibition in a museamizated olive oil mill. Figure 4C. Visitors in a museamizated area in the presentacion of First Day of Harvest, Picualia olive oil mill, Bailén (Jaén Spain). Source: by the authors. 
social behaviour of museum visitors (Tröndle et al. 2012). Based on this line of argument, we formulate the following proposition:

- Proposition 5. The level of resources allocated to promoting the museumization of the olive mill positively influences the degree of museumization of olive oil mills.

\section{Material and methods}

This study is focused on analysing the museumization components of olive oil mills in Andalusia, one of the main olive oil producing regions in the world, where olive oil cooperatives are a reference for their ability to stimulate rural development and preserve their heritage (Montero Aparicio 2008; Puentes Poyatos \& Velasco Gámez 2009; Alonso Logroño \& Bautista Puig 2012). We understand the degree of museumization as an indicator of quality in terms of the implementation of initiatives and elements related to the preservation of heritage, which are considered appropriate and economically acceptable by the organizations or entities (Haro 2012). In order to define the target population, we contacted Designations of Origin and olive oil tourism product clubs such as Oleotour Jaén, Olearum or Oleoturismo Andalucía, which cover the main olive oil mills in the world with museum content. Once the population had been determined, a search was carried out by regions of Andalusia in order to check the selected population and the object of this study. Subsequently, a structured faceto-face survey was given to the organizational heads of these entities, with responses from 46 of the 68 companies selected (67\% response rate).

The study characteristics are detailed in the following table.

\begin{tabular}{|c|c|}
\hline Sample universe & $\begin{array}{l}\text { Olive oil mills belonging to tourist product } \\
\text { clubs or within the network of Andalusian } \\
\text { museumized spaces. }\end{array}$ \\
\hline Geographical scope & Andalusia \\
\hline Time frame & April to June 2021 \\
\hline Population register & $\begin{array}{l}\text { Oleotour Jaén, Olearum and the Andalusian } \\
\text { Network of Museumized Olive Oil Mills } \\
\text { (Oleoturismo Andalucía) }\end{array}$ \\
\hline Universe size & 68 olive oil mills \\
\hline Sampling unit & $\begin{array}{l}\text { Olive oil producer and/or vendor with } \\
\text { museumized tourism activity }\end{array}$ \\
\hline Response rate & $67 \%$ (46 mills) \\
\hline $\begin{array}{l}\text { Profile of } \\
\text { respondents }\end{array}$ & $\begin{array}{l}\text { Directors and technicians of oil mills who } \\
\text { have incorporated content musealization } \\
\text { strategies in them. } 83 \% \text { with higher } \\
\text { education and experience in the } \\
\text { management of museums and interpretation } \\
\text { centres in oil mills. } 54 \% \text { between } 40 \text { and } 55 \\
\text { years. } 66 \% \text { men } 44 \% \text { women }\end{array}$ \\
\hline
\end{tabular}

Table 1.- Technical Data Sheet for the Study
The QCA technique, which is based on Boolean algebra, uses a verbal, conceptual and mathematical language that yields both qualitative and quantitative results, combining the main advantages of the two (Ragin 1987). The application of QCA enables the systematic analysis of a set of cases to determine causal patterns in terms of relationships of necessity and sufficiency between a set of conditions and an outcome (Schneider \& Wagemann 2010). Fuzzy-set QCA (fsQCA) has subsequently become one of the most widely-used QCA variants by overcoming one of the main drawbacks and criticisms of the original csQCA, namely its strictly dichotomous approach (Sehring et al. 2013). The fsQCA technique was developed for small sample or population settings (Ragin 1987), so the small sample universe in this study is not a shortcoming. To properly carry out this technique, the steps recommended in the literature (Schneider \& Wagemann 2012) are followed, focusing on the calibration of the variables as required-both for the conditions and the outcome-followed by the analysis of the necessary conditions and finally the analysis of the sufficient conditions.

The ultimate output of fsQCA is the identification one or several antecedent combinations that are sufficient for obtaining a specific outcome, given as: $X 1 * \sim X 2 * X 3$ sufficient for an outcome $(Y)$. Making use of the symbols employed in this technique $\left(X 1^{*} \sim X 2^{*} X 3->Y\right)$, with $X 1, X 2$ and $X 3$ being antecedents; $Y$ the outcome; * the union; and $\sim$ the absence or negation, in this case the opposite value to X2 (1 - X2).

This methodology helps us to create and establish causal models from surveys that collect the perceptions of the interviewees. Therefore, similar models of museumization, conservation elements, sustainable development indicators (SDG) and other areas susceptible to study could be created, since the innovative nature of this technique offers relevant results.

\section{Results and discussion}

The fsQCA technique is applied together with different variables related to the definition of museumization, which in turn is in line with the definition of museum considered in the study and taken into account when collecting the data. The variables that make up the proposed model are detailed in Table 2.

\section{Source: own production}

The results obtained (Table 3) show that the first configuration presents raw coverage of $59 \%$, pointing to relationships between the degree of museumization of olive oil mills and the promotion of activities linked to the rural and ethnographic development of the territory, the use of objects related to the activity of the mill as a means of interaction and promoting dialogue with the public, and the level of resources allocated to such activities in these mills in order to preserve the heritage of the olive grove. 
that by Farina (2002), who recommends using them to gain an understanding of the dynamics of the changing landscape. As Selman and Knight (2006) points out, resource use and allocation comprises the main element involved in the conservation of ecosystems and the development of traditional agricultural products; as such, the objectives of landscape planning lie partway between the natural-cultural and the socio-economic. The degree of resource use has an exponential effect on the dimensions of innovation in the olive sector, ultimately allowing olive oil mills to set themselves apart at a competitive level (Sánchez-Martínez et al. 2020). The implementation of technological elements and the processes of virtualization of these spaces is becoming common practice and essential to the interaction between the public and the content on offer (Rojas-Sola et al. 2021).

This new model has made it possible to establish causal relationships, in turn enabling the showcasing of olive oil mills as effective museums that foster the development of strategies and tools to prevent the abandonment of olive oil heritage and promote its conservation. However, we have found no other studies on the degree of museumization of olive oil mills in relation to criteria such as the variables used in this model to identify causal relationships. Similarly, no studies to date have assessed the traditional elements to be used in the museumization of olive oil mills or the most relevant aspects in these conversion processes, which may open up new lines of related research in the future.

Olive grove culture should be studied from a multi-faceted perspective that incorporates the aspects related to the most important markers of the integrity of heritage according to UNESCO, as well as the adaptation of olive oil industrial facilities in line with the Cultural Heritage Value Chain. By transforming these spaces into museums to preserve the related artefacts and objects in an inclusive way, with the educational aim of safeguarding their memory, within a scope that includes the heritage values linked to landscapes and the conservation of identity (Antrop 2005), the major cultural value of the traditional olive grove can be preserved and protected.

\section{Conclusions}

This paper has analysed aspects related to the definition of museum that has been the subject of debate within the ICOM, applying the different conceptual areas into which this issue is divided within the context of the museumization of olive oils mills to promote and preserve olive oil heritage. The risk of the traditional olive grove disappearing would entail a very negative environmental impact, as well as being an irreplaceable cultural loss. After conducting a literature review on the definition of a museum and its implications in terms of preserving the cultural heritage of the olive grove, the study addresses key aspects in the museumization process, where the cooperatives act as a driver of development and territorial conservation in rural areas. Moreover, they provide key elements for the development of initiatives related to social innovation applied to the olive oil sector, and the virtualization or modernization of their facilities, which have an impact on new forms of conservation of rural heritage.

Based on the exploration of the progressive proposals for defining a museum within the framework of the study carried out using fsQCA, the results allow us to generate a model of practical application and of novel utility for companies in the olive oil sector. This model will help them implement initiatives aimed at the museumization of olive oil mills to preserve the heritage of olive grove culture. In terms of practical implications, this model contributes to the conservation and enhancement of ethnographic heritage, rural development and the use of resources to revitalize olive oil producing rural areas.

The results of the fsQCA analysis indicated that the degree of museumization of Andalusian olive oil mills is high. These museumized mills, in addition to producing olive oil, implement activities linked to the rural and ethnographic development of the territory, use objects related to the mill's activity as a means of interaction, encourage dialogue with the public, and allocate resources to carry out activities in their facilities. The study of these initiatives is very useful when it comes to fostering the conservation of Andalusian olive oil heritage and the development of future lines of research related to efforts to ensure it remains a cultural touchstone, as it has been over the course of the last five millennia. In this regard, the conservation of the olive grove landscapes and the museumization of olive oil mills can be a spur to take on the challenges facing the rural world of the Mediterranean basin.

\section{References}

ALONSO LOGROÑO, P., BAUTISTA PUIG, N. (2012). “La significación de las cooperativas agrarias en el desarrollo del medio rural: El caso de Guissona". Santiago de Compostela: Proceedings of the Coloquio Ibérico de Geografía, 1334-1344. Available in: https://www.researchgate.net/publication/322357515 in La significacion de las cooperativas agrarias en el desarrollo del medio rural el caso de Guissona [accessed on 03 July, 2021].

ANTROP, M. (2005). “Why landscapes of the past are important for the future?" Landscape and urban planning, 70: 21-34. https:// doi.org/10.1016/j.landurbplan.2003.10.002

ARMESTO LÓPEZ, X. A., GÓMEZ MARTíN, M. B. (2005). “Productos agroalimentarios de calidad y turismo en España: estrategias para el desarrollo local", Geographicalia, 47: 87-110. https://doi. org/10.26754/ojs geoph/geoph.2005471331

BLANCO ROMERO, A. (coord.) (2021). Diccionario de Turismo. Madrid: Cátedra. 
BONTI, M. (2014). "The Corporate Museums and their Social Function: Some Evidence from Italy", European Scientific Journal, 1: 141-150. https://eujournal.org/index.php/esj/article/view/4761

BUCKLEY, R. (2009). "Evaluating the net effects of ecotourism on the environment: A framework, first assessment and future research", Journal of Sustainable Tourism, 17: 643-672. https://doi. org/10.1080/09669580902999188

CARBONE, F., OOSTERBEEK, L., COSTA, C., FERREIRA, A. M. (2020). "Extending and adapting the concept of quality management for museums and cultural heritage attractions: A comparative study of southern European cultural heritage managers' perceptions", Tourism Management Perspectives, 35: 100698. https://doi. org/10.1016/j.tmp.2020.100698

CASTILLO-CANALEJO, A. M., SÁNCHEZ-CAÑIZARES, S. M., SANTOSROLDÁN, L., MUÑOZ-FERNÁNDEZ, G. A. (2020). "Food markets: a motivation-based segmentation of tourists", International Journal of Environmental Research and Public Health 17(7): 2312. https:// doi.org/10.3390/ijerph17072312

CUESTA, M. J., MOYA, E. (2019). “Oleoturismo y desarrollo rural: avances y retos en el caso de la provincia de Jaén (Andalucía, España)". Revista Turismo \& Desenvolvimento, 32: 255-264. https:// doi.org/10.34624/rtd.v0i32.20498

DANILOV, V.J. (1991). Corporate Museums, Galleries, and Visitor Centers: A Directory. New York: Greenwood Press.

DANILOV, V.J. (1992). A Planning Guide for Corporate Museums, Galleries, and Visitor Centers. Westport, C.T: Greenwood Publishing Group.

DEOLEO Group and Vilar Consultores Estratégicos(2019). Informe Salvemos el Buen Aceite. Córdoba: DEOLEO https:// salvemoselbuenaceite.com/ [accessed on 25 June 2021].

DOMON, G., RUIZ, J. (2011). Towards intentional changes of landscape patterns in intensive agricultural areas: the case of Les Maskoutains (Quebec, Canada), Proceeding of IALE, The 8th World Congress of the International Association for Landscape Ecology, Beijing: Beijing, 111-112.

DUARTE, F., JONES, N., FLESKENS, L. (2008). "Traditional olive orchards on sloping land: Sustainability or abandonment?", Journal of Environmental Management 89(2): 86-98. https://doi. org/10.1016/j.jenvman.2007.05.024

El Museo Transformador. Manifiesto (2020). https://www. elmuseotransformador.org/manifiesto/ [accesed on 29 June, 2021].

FARINA, A. (2002). Ecologia del paesaggio: principi, metodi e applicazioni. Bologna: UTET.

FARINA, A., NAVEH, Z. (1993). “Landscape approach to regional planning: the future of the Mediterranean landscapes", Landscape and urban planning, 24: 1-295.
GÓMEZ-LIMÓN, J. A., BARREIRO-HURLÉ, J. (2012). "Valoración económica de las técnicas sostenibles de manejo del suelo en el olivar andaluz", Cuadernos de economía, 35(99): 158-171. https:// doi.org/10.1016/S0210-0266(12)70032-8

GÖSSLING, S. (1999). "Ecotourism: A means to safeguard biodiversity and ecosystem functions?", Ecological economics, 29: 303-320. https://doi.org/10.1016/S0921-8009(99)00012-9

GÖSSLING, S., HANSSON, C. B., HÖRSTMEIER, O., SAGGEL, S. (2002). "Ecological footprint analysis as a tool to assess tourism sustainability", Ecological economics 43: 199-211. https://doi. org/10.1016/S0921-8009(02)00211-2

GULLINO, P., LARCHER, F. (2013). "Integrity in UNESCO World Heritage Sites. A comparative study for rural landscapes", Journal of Cultural Heritage, 14(5): 389-395. https://doi.org/10.1016/j. culher.2012.10.005

HARO, M. (2012). La Puesta en Valor de yacimientos arqueológicos de la Prehistoria Reciente en el sur de la Península Ibérica (Doctoral dissertation: University of Granada).

HERRERO, L.C. (2011). “El Turismo Cultural en España: Un sector estratégico", Papeles de Economía, 128: 123-137. https://www. funcas.es/wp-content/uploads/Migracion/Articulos/FUNCAS PEE/128art12.pdf

International Council Of Museums ICOM, (2019). Museum Definition https://icom.museum/en/resources/standards-guidelines/ museum-definition/ [accessed on 31 May, 2021]

KATRIEL, T. (1994). "Sites of memory: Discourses of the past in Israeli pioneering settlement museums", Quarterly Journal of Speech 80 (1): 1-20 https://doi.org/10.1080/00335639409384052

KIVELA, J., CROTTS, J. C. (2006). "Tourism and gastronomy: gastronomy's influence on how tourists experience a destination", Journal of Hospitality \& Tourism Research, 30 (3): 354-377. https:// doi.org/10.1177\%2F1096348006286797

KIROVA, V. (2020). "Value co-creation and value co-destruction through interactive technology in tourism: the case of 'La Cité du Vin' wine museum, Bordeaux, France", Current Issues in Tourism, 24(5): 637-650. https://doi.org/10.1080/13683500.2020.1732883

LOUMOU, A., GIOURGA, C. (2003). "Olive groves: The life and identity of the Mediterranean", Agriculture and Human Values 20(1): 87-95. https://dx.doi.org/10.1023/A:1022444005336

MATRICANO, D. (2017). Applying seci model to transfer organizational memory through corporate museums. C. C. Vrontis D., Weber Y., Tsoukatos, E. (Eds.), Global and national business theories and practice: bridging the past with the future: 1031-1038. Euromed Press. https://emrbi.org/wp-content/uploads/2020/09/ EuroMed-10-2017.pdf [accesed on 16 June 2021].

MONTELLA, M. M. (2017). "Wine tourism and sustainability: A review", Sustainability, 9(1): 113. https://doi.org/10.3390/su9010113 
MONTERO APARICIO, A. (2008). La Economía Socialy su Participación en el Desarrollo Rural. Madrid: Fundación Alternativas.

MOZAS-MORAL, A. (2019). Contribución de las Cooperativas Agrarias al Cumplimiento de los Objetivos de Desarrollo Sostenible. Especial Referencia al Sector Oleícola. Centro internacional de investigación e información sobre la economía pública, social y cooperativa: Ciriec, España

MOZAS-MORAL, A., BERNAL-JURADO, E., FERNÁNDEZ-UCLÉS, D., MEDINA-VIRUEL, M. J. (2020). "Innovation as the Backbone of Sustainable Development Goals", Sustainability 12(11): 4747. https://doi.org/10.3390/su12114747

NAVEH, Z., LIEBERMANN, A. (1994). A Landscape Ecology, New York: Springer Edition.

NISSLEY, N., CASEY, A. (2002). "The politics of the exhibition: Viewing corporate museums through the paradigmatic lens of organizational memory", British Journal of Management, 13(1): 3545. https://doi.org/10.1111/1467-8551.13.s2.4

OJEDA-RIVERA, J.F., ANDREU-LARA, C., INFANTE-AMATE, J. (2018). "Razones y recelos de un reconocimiento patrimonial: los paisajes del olivar andaluz", Boletín de la Asociación de Geógrafos Españoles 79, 2471: 1-29. http://dx.doi.org/10.21138/bage.2471

O'REILLY, C., LAWRENSON, A. (2020). "Democratising audience experience: making space for families in blockbuster exhibitions", Museum Management and Curatorship, 36(2): 136-153 https://doi. org/10.1080/09647775.2020.1766995

ORTEGA-ALONSO, D., PADILLA-FERNÁNDEZ, J. J. (2019). "Arte público, ciencia y patrimonio en el entorno rural: el caso de murales conciencia", Ge-Conservación 16: 204-214. https://doi. org/10.37558/gec.v16i0.709

PETRUZZELLA, D., JAWHAR J. (eds.) (2020). MIP Report 2020. Innovation in the Mediterranean agrifood sector: actors, policies and future prospects in a developing ecosystem. CIHEAM Bari: Valenzano. https://mip.iamb.it/wp-content/uploads/2018/06/ReportMIP2017 def.pdf

PARRILLA-GONZÁLEZ, J. A., MURGADO-ARMENTEROS, E. M., TORRES-RUIZ, F. J. (2020). "Characterization of Olive Oil Tourism as a Type of Special Interest Tourism: An Analysis from the Tourist Experience Perspective", Sustainability 12: 6008. https://doi. org/10.3390/su12156008

PARRILLA-GONZÁLEZ, J. A., PULIDO-FERNÁNDEZ, J. I. (2017). "Inteligencia territorial y turismo. Hacia la integración de un modelo de transformación económica", Estudios y perspectivas en turismo 26(1): 1-21. https://www.redalyc.org/articulo. oa?id=180749182001

PASSEBOIS DUCROS, J., EUZÉBY, F. (2019). "Investigating consumer experience in hybrid museums: a netnographic study", Qualitative Market Research Vol. 24 № 2: 180-199. https://doi.org/10.1108/ QMR-07-2018-0077
PUENTES POYATOS, R., VELASCO GÁMEZ, M. M. (2009). "Importancia de las sociedades cooperativas como medio para contribuir al desarrollo económico, social y medioambiental, de forma sostenible y responsable", Revesco, Revista de Estudios Cooperativos, 99: 104-129. https://www.redalyc.org/articulo. $\underline{\text { oa? id }=36711903005}$

RAGIN, C. C. (1987). The comparative method: moving beyond qualitative and quantitative strategies. Berkeley, CA: University of California Press.

RIHOUX, B., RAGIN, C. C. (2009). Configurational comparative methods: Qualitative comparative analysis (QCA) and related techniques. California: Sage Publications.

ROJAS-SOLA, J.I., CASTRO-GARCIA, M., CARRANZA-CANADAS, M.P. (2021). "Content management system incorporated in a virtual museum hosting", Journal of Cultural Heritage, 12: 74-81. https:// doi.org/10.1016/j.culher.2010.10.004

SÁNCHEZ-MARTÍNEZ, J. D., RODRÍGUEZ-COHARD, J. C., GARRIDOALMONACID, A., GALLEGO-SIMÓN, V. J. (2020). "Social Innovation in Rural Areas? The Case of Andalusian Olive Oil Co-Operatives", Sustainability, 12: 10019. https://doi.org/10.3390/su122310019

SCAZZOSI, L. (2004). "Reading and assessing the landscape as cultural and historical heritage", Landscape Research, 29(4): 335355. https://doi.org/10.1080/0142639042000288993

SCHNEIDER, C. Q., WAGEMANN, C. (2010). "Standards of good practice in qualitative comparative analysis (QCA) and fuzzy-sets", Comparative Sociology 9(3): 397-418. https://doi.org/10.1163/1569 $\underline{13210 \times 12493538729793}$

SCHNEIDER, C. Q., WAGEMANN, C. (2012). Set-theoretic methods for the social sciences: A guide to qualitative comparative analysis. Cambridge: Cambridge University Press.

SEHRING, J., KORHONEN, K., BROCKHAUS, M. (2013). Qualitative Comparative Analysis (QCA): An application to compare national REDD+ policy processes, 21. Indonesia: CIFOR.

SELMAN, P., KNIGHT, M. (2006). "On the nature of virtuous change in cultural landscapes: exploring sustainability through qualitative models", Landscape Research, 31(3): 295-307. https://doi. org/10.1080/01426390600783517

TREGUA, M., D'AURIA, A., MARANO-MARCOLINI, C. (2018). "Oleotourism: local actors for local tourism development", Sustainability, 10(5): 1492. https://doi.org/10.3390/su10051492

TRÖNDLE, M., WINTZERITH, S., WÄSPE, R., TSCHACHER, W. (2012). “A museum for the twenty-first century: the influence of 'sociality' on art reception in museum space", Museum Management and Curatorship, 27(5): 461-486. https://doi.org/10.1080/09647775.2012.737615

UNESCO (1962). Recommendation concerning the safeguarding of the beauty and character of Landscapes and sites, https://unesdoc.unesco. org/ark:/48223/pf0000114582.page=142 [accessed 25 June, 2021]. 
UNWTO/UNESCO (2018). Conference: Cultural Tourism Sustains Communities and Living Heritage https://www.unwto.org/europe/ press-release/2018-12-05/unwtounesco-conference-cultural-tourismsustains-communities-and-living-her [accessed 25 June, 2021].

VARGAS-SÁNCHEZ, A. (2015). "Industrial heritage and tourism: A review of the literature", The Palgrave handbook of contemporary heritage research, 219-233. https://doi. org/10.1057/9781137293565 14

VILAR HERNÁNDEZ, J., VELASCO GÁMEZ, M.D.M., PUENTES POYATOS, R. (2010). "Incidencia del modo de explotación del olivo sobre la renta neta del olivicultor. Estrategias para el cultivo extensivo en el contexto de la posible ausencia de subvenciones", Grasas yaceites 61(4): 430-440. https://doi.org/10.3989/gya.010210

VV.AA. (2007). International Expert Workshop on Integrity and Authenticity of World Heritage Cultural Landscapes, Proceedings, Aranjuez: Spain: http://whc.unesco.org/uploads/events/ documents/event-450-1.pdf [accesed on 6 July, 2021].

WEAVER, D. B. (2002). "The evolving concept of ecotourism and its potential impacts", International Journal of Sustainable Development (IJSD), 5(3): 251-264. https://dx.doi.org/10.1504/IJSD.2002.003753

\section{Author/s}
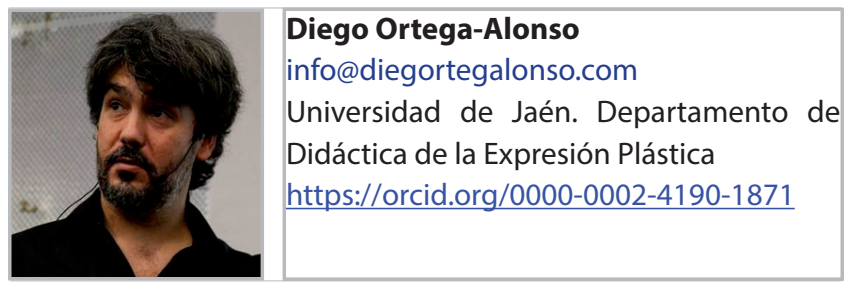

Licenciado en Bellas Artes por la Universidad de Granada. Máster en Investigación y Educación Estética y Doctor Internacional en Patrimonio por la Universidad de Jaén, con la calificación CUM LAUDE. Sus líneas de trabajo tienen un carácter marcadamente interdisciplinar, abordando áreas que van desde la actividad artística hasta investigación en patrimonio, comunicación de la ciencia a través de las artes, educación artística, ilustración científica, implementación de proyectos de innovación social o inclusión de las personas con discapacidad intelectual y otros colectivos en riesgo de exclusión social a través de las artes y la divulgación científica. Agente de Innovación del Ayuntamiento de Bailén y finalista al mejor e-facilitador europeo en 2020 , también ha sido responsable e IP de varios proyectos financiados por la Fundación Española para la Ciencia y la Tecnología en diferentes convocatorias para el Fomento de la Cultura Científica, Tecnológica y de la Innovación. Su currículum incluye más de una treintena de artículos y publicaciones en las que ha participado como autor o como colaborador con sus ilustraciones y pinturas, así como varios premios nacionales e internacionales de carácter artístico o relativos a la comunicación de la ciencia a través del arte y la innovación social. En el ámbito de la pintura y la ilustración científica, además de exponer sus obras en España, Ecuador, Portugal, Argentina o Colombia, destaca por su actividad docente impartiendo talleres, conferencias y simposios en universidades, centros de investigación o espacios naturales tan relevantes como la Pontificia Universidad Católica de Quito, Mashpi Lodge (National Geographic, Ecuador), Universidad de Sevilla, Museo Nacional de Ciencias Naturales de Madrid, Yacimientos de Atapuerca (España), o Parque Nacional del Serengeti (Tanzania). Sus obras han sido publicadas en revistas científicas, tesis doctorales, libros de texto, material docente y otras publicaciones.

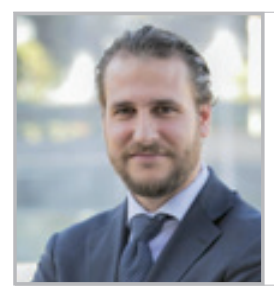

\section{Juan Antonio Parrilla-González}

japarril@ujaen.es

Universidad de Jaén. Departamento de Economía

https://orcid.org/0000-0003-3849-8775

Diplomado en Ciencias Empresariales y Licenciado en Administración y Dirección de Empresas por la Universidad de Jaén. Máster Oficial en Economía y Desarrollo Territorial por las Universidades de Jaén, Huelva, Cádiz y Doctor en Ciencias Sociales y Jurídicas con la calificación CUM LAUDE. Sus líneas de investigación se centran en el sector de los aceites de oliva y la cultura del olivar desde una perspectiva multidisciplinar destacando trabajos relacionados con el oleoturismo, la innovación social y la utilización de almazaras como entidades útiles para desarrollar iniciativas educativas, patrimoniales y diversificadoras. Se incluyen diversos capítulos de libro y monografías en torno a las almazaras cooperativas como instrumentos de dinamización del territorio, así como diferentes artículos de investigación de impacto en el Journal Citation Index relacionados con el sector del olivar. Desde 2015 realiza labores de coordinador de diversas entidades cooperativas y almazaras, ejerciendo como secretario del Centro de Interpretación de Olivar y Aceite situado en Úbeda (Jaén). A partir de 2017 se han sucedido varios contratos de transferencia de investigación con la empresa Picualia (Bailén, Jaén), considerada una de las almazaras modelo del siglo XXI y premiada como Mejor Almazara de España. Actualmente ejerce como Profesor Interino en el Departamento de Economía de la Universidad de Jaén desde Septiembre de 2017. Destaca la Codirección del Experto Universitario en Redes Sociales y Comercio Electrónico aplicado al sector del olivar en la Universidad internacional de Andalucía, y la docencia y organización de distintos Tribunales de Evaluación de la Escuela Internacional de Gerencia (Granada) y de ESIC: Business School. En la Universidad de Jaén la docencia impartida tanto en grados como Másters se caracteriza por ser variada y bilingüe.
Artículo enviado el 31/08/2021 Artículo aceptado el 21/10/2021

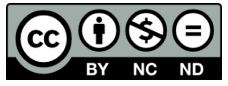

https://doi.org/10.37558/gec.v20i1.1036 